\title{
PENGAWASAN PENGGUNAAN TENAGA KERJA ASING DI SUMATERA BARAT
}

\author{
Lerri Pattra \\ Faculty of Law, Universitas Andalas. E-mail: lerripattra@yahoo.co.id
}

\begin{abstract}
The Republic of Indonesia was founded, the Indonesian people have realized that work is a human need for citizens. This is stated and mandated in Article 27 paragraph (2) of the 1945 Constitution which states that "Every citizen has the right to work and a living that is decent for humanity". This has implications for the state's obligation to facilitate citizens to obtain decent work for humanity. However, recently the use of foreign workers has become one of the main issues in Indonesia. Foreign workers are foreign nationals holding visas with the intention of working in Indonesian territory. Constitutionally, the use of foreign workers in Indonesia is regulated in Law no. 13/2003 concerning Manpower and strengthened by Law no. 25 of 2007 concerning Investment. Thus the use of foreign workers cannot be avoided because it is constitutionally very possible. Another factor that influences the presence of foreign workers in Indonesia is the agreement of the ASEAN Economic Community (AEC) which began in 2015. This has provided opportunities for the free use of foreign workers for the ASEAN region. What has always been a problem is the high unemployment rate caused by the lack of employment opportunities for Indonesian citizens.
\end{abstract}

Keywords: Foreign Workers, ASEAN Economic Community, Investment

\section{Pendahuluan}

Sejak Negara RI didirikan, bangsa Indonesia telah menyadari bahwa pekerjaan merupakan kebutuhan asasi warga Negara. Hal ini dituangkan dan diamanatkan dalam Pasal 27 ayat (2) UUD 1945 yang menyatakan bahwa "Tiap-tiap warga negara berhak atas pekerjaan dan penghidupan yang layak bagi kemanusiaan". Hal tersebut berimplikasi pada kewajiban negara memfasilitasi warga negara agar memperoleh pekerjaan yang layak bagi kemanusiaan. Oleh karena itu, perlu perencanaan matang di bidang ketenagakerjaan untuk mewujudkan kewajiban negara tersebut. ${ }^{1}$

Dalam Pasal 5 Undang-undang Nomor 13 Tahun 2003 Tentang Ketenagakerjaan (selanjutnya disebut dengan UU Ketenagakerjaan) dinyatakan bahwa: Setiap tenaga kerja memiliki kesempatan yang sama tanpa diskriminasi untuk memperoleh pekerjaan, Selanjutnya dalam Pasal 31 UU Ketenagakerjaan menyatakan bahwa: Setiap tenaga kerja mempunyai hak dan kesempatan yang sama untuk memilih, mendapatkan, atau pindah pekerjaan, dan memperoleh penghasilan yang di dalam atau diluar negeri.

\footnotetext{
${ }^{1}$ Adrian Sutedi, 2009, Hukum Perburuhan, Sinar Grafika, Jakarta, hlm. 1.
} 
Penggunaan Tenaga Kerja Asing diatur dalam Pasal 42 - 49 UU No 13 Thn 2003

1. Setiap pemberi kerja yang mempekerjakan tenaga asing wajib memiliki izin tertulis dari Menteri atau Pejabat yang ditunjuk.

2. Pemberi kerja yang menggunakan tenaga kerja asing harus memiliki rencana penggunaan tenaga kerja asing yang disahkan oleh Menteri atau Pejabat yang ditunjuk.

Rencana Penggunaan tenaga kerja asing sekurang-kurangnya memuat:

1. Alasan penggunaan tenaga kerja asing.

2. Jabatan dan/atau kedudukan tenaga kerja asing dalam struktur organisasi perusahaan yang bersangkutan

3. Jangka waktu penggunaan tenaga kerja asing

4. Penunjukan tenaga kerja warga negara Indonesia sebagai pendamping tenaga kerja asing yang dipekerjakan

Isu tenaga kerja masih menjadi fokus pembicaraan sejumlah pihak pasca menjadi salah satu topik yang dibahas pada pegelaran debat calon wakil presiden. Salah satu fokusnya adalah derasnya aliran tenaga kerja asing yang masuk dalam beberapa tahun terakhir. Berdasarkan data yang dirilis oleh Kementerian Ketenagakerjaan Republik Indonesia (Kemenaker), pada tahun 2018, terdapat setidaknya 95.335 orang TKA yang tercatat resmi bekerja di Indonesia. Jumlah tersebut merupakan yang paling tinggi sejak tahun 2011. Sejak Presiden Joko Widodo (Jokowi) memegang kendali atas pemerintahan Indonesia, pertumbuhan TKA memang cukup pesat.. Sepanjang periode 2015-2018, rata-rata laju pertumbuhan TKA di tanah air mencapai 8,66\%. Padahal pada periode 2011-2014, rata-rata pertumbuhan TKA tercatat negatif alias berkurang sebesar 8,95\%. Berdasarkan kewarganegaraan, TKA asal China merupakan yang memiliki pertumbuhan paling pesat. Sepanjang 2015-2018 rata-rata pertumbuhan TKA Negeri Panda berada pada level 18,79\%. Disusul oleh TKA asal India yang rata-rata pertumbuhannya mencapai 9,51\% pada periode yang sama. Hal ini tampaknya tidak terlepas dari banyaknya proyek-proyek kerjasama pembangunan infrastruktur antara Indonesia dengan China. Sebut saja megaproyek kereta cepat Jakarta-Bandung yang secara resmi melibatkan China, setelah Jokowi menerbitkan Peraturan Presiden Nomor 107 Tahun 2015 tentang Penyelenggaraan Prasarana dan Sarana Kereta Cepat Jakarta-Bandung. Keputusan yang diambil kala itu memang sempat memantik kontroversi. Ini lantaran sebelumnya pemerintah juga sempat memberikan sinyal bagi Jepang untuk mengerjakan proyek ambisius tersebut. ${ }^{2}$

Direktur Jenderal Pembinaan Penempatan Tenaga Kerja dan Perluasan Kesempatan Kerja Kementerian Ketenagakerjaan (Kemnaker) Maruli Apul Hasoloan menjelaskan, jumlah TKA sampai akhir 2018 lalu mencapai 95.335 orang. Angka ini meningkat 10,88 persen dibanding sepanjang 2017 lalu yang mencapai 85.974 orang. Jika diperinci, dari TKA berjumlah 95.335 orang itu terdapat tenaga asing profesional

https://www.cnbcindonesia.com/news/20190318150352-4-61343/double-digit-data-pertumbuhantenaga-kerja-asing-dari-china 
yang menyumbang sebesar 30.626 orang, manajer sebanyak 21.237 orang, dan adviser/konsultan/direksi sebanyak 30.708 orang. Dia menyebutkan, jumlah TKA yang bekerja di Indonesia itu masih dalam level tenaga profesional bukan buruh kasar yang tidak memiliki skill. Baca juga: Dalam 5 Tahun, Jepang Bakal Kebanjiran 345.000 Pekerja Asing. Kenaikan tenaga kerja asing di Indonesia seiring dengan peningkatan investasi asing. Adapun jika dilihat dari negara asalnya, sampai 2018 TKA yang bekerja di Indonesia masih didominasi dari China dengan jumlah 32.000 orang. Setelah itu berturut-turut, Jepang 13.897 orang, Korea 9.686 orang, India 6.895 orang, dan Malaysia 4.667 orang. Per tahunnya siklus negara-negara tersebut saja yang mendominasi di Indonesia.

Saat ini Kemenaker sendiri tengah fokus menggenjot kualitas sumber daya manusia (SDM). Berbagai program kerja yang menjadi prioritas seperti memperbanyak pelatihan kerja calon pekerja migran Indonesia (CPMI), kegiatan pemagangan dan peningkatan infrastruktur Balai Latihan Kerja (BLK). Sekedar informasi, pada tahun lalu, Kemnaker membentuk satuan tugas (satgas) pengawasan TKA. Satgas ini berfungsi untuk menjembatani aspirasi dari masyarakat terkait pelanggaran yang terjadi. Dengan begitu, pengawasan akan lebih terintegrasi karena melibatkan kementerian dan lembaga terkait lainnya.

Untuk daerah Sumatera Barat, Dinas Tenaga Kerja dan Transmigrasi (Disnakertrans) Sumatera Barat mencatat, ada sebanyak 51 tenaga kerja asing (TKA) yang bekerja di 33 perusahaan yang tersebar di Sumatera Barat. Sejumlah 51 TKA itu berasal dari berbagai negara yakni dari Australia, India, Malaysia, Inggris, Spanyol, China, Amerika Serikat, Filipina, Singapura, dan Belgia. Di antara mereka, kebanyakan merupakan TKA yang berasal dari Malaysia dan Cina. Jjumlah TKA termasuk yang sedikit dibandingkan dengan provinsi lain di Indonesia. Apalagi di Sumatera Barat, tidak terlalu banyak perusahaan yang memakai tenaga kerja asing. Saat ini ada sekitar 6.000 lebih buruh yang bekerja di seluruh daerah di Sumatera Barat. Untuk meningkatkan kualitas buruh dan calon pekerja pihak terus melakukan gebrakan seperti memberikan pelatihan lewat Balai Pelatihan kerja. ${ }^{3}$

Untuk memastikan terlaksananya penyelenggaraan hubungan industrial yang baik di Sumatera Barat, terutama tentang penggunaan tenaga kerja asing, maka diperlukan adanya pengawasan yang dalam hal ini dilakukan oleh Dinas Tenaga Kerja dan Transmigrasi Provinsi Sumatera Barat. Berdasarkan hal tersebut permasalahan yang dihadapi, yaitu : Bagaimana Pengawasan Tenaga Kerja Asing di Sumatera Barat? dan Apa kendala dalam Pengawasan Tenaga Kerja Asing di Sumatera Barat?

\footnotetext{
${ }^{3}$ https://kumparan.com/langkanid/ada-51-tka-di-sumatera-barat
} 


\section{Pembahasan}

\section{A. Tinjauan Tentang Pengawasan}

\section{Pengertian Pengawasan}

Agar tetap terpeliharanya stabilitas dan kepentingan nasional, kedaulatan negara, keamanan dan ketertiban umum, dan kewaspadaan terhadap segala dampak negatif yang timbul akibat perlintasan orang antar Negara, keberadaan, dan kegiatan orang asing di wilayah Negara Kesatuan Republik Indonesia, dipandang perlu melakukan pengawasan bagi orang asing dan tindakan keimigrasian seacara cepat, teliti, koordinasi, tanpa mengabaikan keterbukaan dalam meberikan pelayanan bagi orang asing. Tujuan pengawasan adalah untuk mengetahui dan menilai kenyataan yang sebenarnya tentang pelaksanaan tugas dan pekerjaan, apakah sesuai dengan yang semestinya atau tidak. ${ }^{4}$

\section{Kewenangan Pengawasan}

Pasal 1 angka 6 Undang-Undang Nomor 30 Tahun 2014 tentang Administrasi Pemerintahan menyebutkan pengertian kewenangan adalah kekuasaan Badan dan/atau Pejabat Pemerintahan atau penyelenggara negara lainnya untuk bertindak dalam ranah hukum publik.

Kewenangan memiliki kedudukan penting dalam kajian Hukum Tata Negara dan Hukum Administrasi Negara..$^{5}$ Menurut H.D Stout wewenang adalah pengertian yang berasal dari hukum organisasi pemerintahan, yang dapat dijelaskan sebagai seluruh aturan-aturan yang berkenaan dengan perolehan dan penggunaan wewenang-wewenang pemerintahan oleh subjek hukum publik di dalam hubungan hukum publik. ${ }^{6}$ Menurut Bagir Manan wewenang dalam bahasa hukum tidak sama dengan kekuasaan. Kekuasaan hanya menggambarkan hak untuk berbuat dan tidak berbuat. Dalam hukum, wewenang sekaligus berarti hak dan kewajiban (rechten en plicten). Dalam kaitannya dengan otonomi daerah, hak mengandung pengertian kekuasaan untuk mengatur sendiri (zelfregelen) dan mengelola sendiri (zelfbesturen), sedangkan kewajiban secara horizontal berarti kekuasaan untuk menyelenggarakan pemerintahan sebagaimana mestinya. Vertikal berarti kekuasaan untuk menjalankan pemerintahan dalam satu tertib ikatan pemerintahan negara secara keseluruhan. ${ }^{7}$

\section{Pengawasan Keimigrasian Terhadap Orang Asing}

Pengawasan terhadap orang asing merupakan proses kegiatan di bidang Keimigrasian yang mengumpulkan data dan informasi, menganalisa dan menentukan apakah keberadaan orang asing sejak masuknya di Wilayah Indonesia dan kegiatannya selama berada di Wilayah Indonesia telah sesuai dengan norma yang berlaku baginya. Pengaturan tentang Pengawasan Keimigrasian diatur dalam Pasal 66-73 Undang-Undang Keimigrasian. Yang

\footnotetext{
${ }^{4}$ Jum Anggriani,2012, Hukum Administrasi Negara, Graha IImu,Yogyakarta, hlm. 79

${ }^{5}$ Ridwan HR, 2013, Hukum Administrasi Negara, Rajawali Pers, Jakarta, hlm. 99.

${ }^{6} \mathrm{Ibid}, \mathrm{hlm} .98$

${ }^{7} \mathrm{lbid}, \mathrm{hlm} .99$
} 
menjadi objek pengawasan Keimigrasian adalah warga negara Indonesia yang berada di dalam maupun di luar wilayah Indonesia dan warga negara asing yang berada di Wilayah Indonesia. ${ }^{8}$

\section{a Pengawasan Administratif}

Adalah pengawasan yang dilakukan melalui penelitian surat-surat dokumen, berupa pencatatan, pengumpulan, pengolahan data, dan penyajian maupun penyebaran informasi secara manual dan elektronik, tentang lalu lintas keberadaan dan kegiatan orang asing. ${ }^{9}$

Pengawasan administratif kepada orang asing dilakukan berupa:

1) Pengumpulan, pengolahan serta penyajian data dan informasi mengenai: Pelayanan keimigrasian bagi orang asing, Lalu lintas orang asing yang masuk atau keluar Wilayah Indonesia, Orang asing yang telah mendapatkan keputusan pendetensian, Orang asing yang dalam proses penentuan status Keimigrasian, Orang asing yang mendapatkan izin berada diluar Rumah Detensi Imigrasi setelah terlampauinya jangka waktu pendetensian, Orang asing dalam proses peradilan pidana

2) Penyusunan daftar nama orang asing yang dikenai penangkalan atau pencegahan

3) Pengambilan foto dan sidik jari. ${ }^{10}$

\section{b Pengawasan Lapangan}

Adalah pengawasan yang dilakukan berupa pemantauan, patroli, proses dengan mengumpulkan bahan keterangan pencarian orang, dan alat bukti yang berhubungan dengan Tanda Pengenal Keimigrasian. ${ }^{11}$ Pengawasan lapangan terhadap orang asing dilakukan sebagai berikut:

1) Pengawasan terhadap keberadaan dan kegiatan orang asing di Wilayah Indonesia, meliputi pengecekan: Keberadaan orang asing, Kegiatan orang asing, Kelengkapan dokumen perjalan atau izin tinggal yang dimiliki

2) Melakukan kegiatan lain yang dapat dipertanggungjawabkan secara hukum, berupa: Melaksanakan kewenangan Keimigrasian sesuai denga ketentuan peraturan perundang-undangan, Melakukan koordinasi antar instansi dan/atau lembaga pemerintahan dengan pengawasan Keimigrasian. ${ }^{12}$

\footnotetext{
${ }^{8}$ Jazim Hamidi dan Charles Christian, Op.Cit., hlm.83

${ }^{9}$ Ibid,

${ }^{10}$ Jazim Hamidi dan Charles Christian, Op.Cit., hlm 87

${ }^{11}$ Sihar Sihombing, Op.Cit., hlm.88

12 Jazim Hamidi dan Charles Christian, Op.Cit., hlm.88
} 


\section{Tim Pengawasan Orang Asing}

Agar tercipta kondisi yang tertib dalam Keimigrasian, perlu dilakukan pengawasan yang berkesinambungan. Untuk melakukan pengawasan Keimigrasian terhadap kegiatan orang asing di Wilayah Indonesia, Menteri membentuk Tim Pengawasan Orang Asing yang anggotanya terdiri atas badan atau instansi pemerintah, terkait di Pusat maupun di Daerah. Menteri atau Pejabat Imigrasi yang ditunjuk bertindak selaku Ketua Tim Pengawasan Orang Asing. ${ }^{13}$

Berdasarkan Pasal 1 angka 2 Peraturan Menteri Hukum Dan Hak Asasi Manusia Republik Indonesia Nomor 50 Tahun 2016 tentang Tim Pengawasan Orang Asing menyatakan bahwa Tim Pengawasan Orang Asing yang selanjutnya disebut Tim Pora adalah tim yang terdiri dari instansi dan/atau lembaga pemerintah yang mempunyai tugas dan fungsi terkait dengan keberadaan dan kegiatan Orang Asing. Pembentukan Tim Pora dimaksudkan untuk mewujudkan pengawasan keimigrasian yang terkoordinasi dan menyeluruh terhadap keberadaan dan kegiatan Orang Asing di Wilayah Indonesia. Tim pengawasan orang asing bertugas memberikan saran dan pertimbangan kepada badan atau instansi pemerintah yang bidang tugasnya menyangkut pengawasan orang asing.

\section{B. Tinjauan tentang Tenaga Kerja Asing}

\section{Dasar Hukum}

Tenaga kerja asing adalah warga negara asing pemegang visadengan maksud bekerja di wilayah Indonesia. ${ }^{14}$ Secara konstitusional Penggunaan TKA di Indonesia diatur dalam UU No. 13 TAhun 2003 Tentang Ketenagakerjaan dan diperkuat dengan UU No. 25 Tahun 2007 Tentang Penanaman Modal. Dengan demikian penggunaan Tenaga Kerja Asing tidak dapat dihindari karena secara konstitusional hal tersebut sangat dimungkinkan. Faktor lain yang berpengaruh terhadap kehadiran Tenaga Kerja Asing di Indonesiaadalah karena telah adanya kesepakatan Masyarakat Ekonomi ASEAN (MEA) yang dimulai sejak tahun 2015. Hal inilah yang memberi peluang lalu lintas penggunaan Tenaga Kerja Asing secara bebas untuk kawasan ASEAN

\section{Tujuan}

Ditinjau dari aspek ketenagakerjaan, tujuan penggunaan Tenaga Kerja Asing adalah untuk menjamin dan memberi kesempatan kerja yang layak bagi warga negara asing di berbagai lapangan dan level, karenanya dalam mempekerjakan TKA harus dilakukan melalui mekanisme dan prosedur yang ketat, dimulai dengan seleksi dan prosedur perizinan serta pengawasan. ${ }^{15}$ Adapun tujuan lainnya yaitu: a). Untuk memenuhi kebutuhan tenaga kerja terampil dan profesional di bidang tertentu yang belum dapat diisi ileh

\footnotetext{
$13 \mathrm{lbid}, \mathrm{h} / \mathrm{m} 88$

14 Khairani, 2018, Pemgantar Hukum Perburuhan dan Ketenagakerjaan,RajaGrafindo Persada, Depok, hlm.48

15 Fankiano B Randang, 2011, Kesiapan Tenaga Kerja Indonesia dalam menghadapi Persaingan Tenaga Kerja Asing, Servanda, Jurnal IImiah Hukum vpl, 5 No.1, Januari 2011, ISSN 1907-162030, hlm 66
} 
tenaga kerja Indonesia, b). Mempercepet proses pembangunan nasional dengan jalan mempercepat proses alih ilmu pengetahuan dan teknologi, c). Untuk memberikan perluasan kesempatan kerja bagi tenaga kerja di Indonesia, d). Meningkatkan investasi asing sebagai penunjang modal pembangunan di Indonesia

\section{Syarat untuk Mempekerjakan Orang Asing di Indonesia}

Pada prinsipnya perusahaan yang ada dilndonesia wajib menggunakan tenaga ahli bangsa Indonesia. Namun, apabila hal tersebut tidak bisa diisi oleh pekerja Indonesia, maka dibolehkan menggunakan pekerja asing. Peluang ini dijamin secara konstitusional di Indonesia melalui Pasal 10 ayat (2) UU No.25 Tahun 2007 Tentang Penanaman Modal yang menyebutkan bahwa perusahaan penanam modal berhakmenggunakan tenaga ahli warga negara asing untuk jabatan dan keahlian tertentu sesuai dengan ketentuan perundang-undangan. Ketentuan ini memberipeluang bagi pemodal asing untuk mempergunakan TKA yang akan bekerja di perusahaannya dengan syarat harus ada alih teknologi pada Tenaga Kerja Indonesia (TKI). Selanjutnya dalam Pasal 42 - 49 UU No.13 Tahun 2003 Tentang Ketenagakerjaan diatur kriteria dan persyaratan bagi Tenaga Kerja Asing yang kan bekerja di Indonesia.

\section{Tinjauan Tentang Pengawasan Ketenagakerjaan}

Pasal 1 Angka 32 UU No 13 Tahun 2003 Tentang Ketenagakerjaan, menyatakan bahwa Pengawasan ketenagakerjaan adalah kegiatan mengawasi dan menegakkan pelaksanaan peraturan perundang-undangan di bidang ketenagakerjaan. Dalam UU 23 Tahun 2014, urusan pengawasan ketenagakerjaan merupakan urusan wajib dan bersifat konkuren antara Pemerintah Pusat dan Pemerintah Daerah Provinsi. Berdasarkan lampiran Undang-Undang Nomor 23 Tahun 2014 disebutkan penetapan sistem pengawasan ketenagakerjaan dan pengelolaan tenaga pengawas ketenagakerjaan menjadi urusan Pemerintah Pusat, sedangkan kewenangan penyelenggaraan pengawasan ketenagakerjaan menjadi urusan Pemerintah Daerah Provinsi

Dalam Pasal 102 ayat (1) UU No. 13 Tahun 2003 dinyatakan bahwa dalam pelaksanaan Hubungan Industrial pemerintah mempunyai fungsi, yaitu: a). Menetapkan kebijakan, b). Memberikan pelayanan, c). Melaksanakan pengawasan, d). Melakukan penindakan terhadap pelanggaran peraturan perundang-undangan ketenagakerjaan.

Pengawasan Pemerintah ini juga kembali dinyatakan dalam Pasal 134 UU No 13 Tahun 2003 yang menyatakan bahwa: Dalam mewujudkan pelaksanaan hak dan kewajiban pekerja/buruh dan pengusaha, pemerintah wajib melaksanakan pengawasan dan penegakan peraturan perundang-undangan ketenagakerjaan. Pengaturan lain mengenai pengawasan ini diatur dalam Pasal 176 - Pasal 181 UU No 13 Tahun 2003, dimana dalam ketentuan ini menyatakan bahwa: Pengawasan ketenagakerjaan dilakukan oleh pegawai pengawas ketenagakerjaan yang mempunyai kompetensi dan independen guna menjamin pelaksanaan peraturan perundang-undangan 
ketenagakerjaan. Pegawai pengawas ketenagakerjaan ditetapkan oleh Menteri atau pejabat yang ditunjuk. Pengawasan ketenagakerjaan dilaksanakan oleh unit kerja tersendiri pada instansi yang lingkup tugas dan tanggung jawabnya di bidang ketenagakerjaan pada pemerintah pusat, pemerintah provinsi dan pemerintah kabupaten/kota. Unit kerja pengawasan ketenagakerjaan pada pemerintah provinsi dan pemerintah kabupaten/kota wajib menyampaikan laporan pelaksanaan pengawasan ketenagakerjaan kepada Menteri.

\section{Metode Penelitian}

Dalam penelitian yang akan membahas dan membahas dan mengkaji tentang Pengawasan Penggunaan Tenaga Kerja Asing di Sumatera Barat, pendekatan yang digunakan dalam penelitian ini adalah pendekatan hukum empiris (yuridis sosiologis/ socio legal research) yang melihat kepada aturan-aturan sebagai acuan serta membandingkan pelaksanaannya dengan kenyataan di lapangan.

\section{Hasil Penelitian}

\section{A. Pengawasan Tenaga Kerja Asing di Sumatera Barat}

Pengawasan terhadap penggunaan Tenaga Kerja Asing dilakukan dengan cara membuat sistem perizinan bagi TKA, mengendalikan penggunaan TKA dan dilakukan pengawasan terhadap TKA. Maka untuk itu Peraturan perundanganundangan mengenai penggunaan TKA terhadap perlindungan tenaga kerja Warga Negara Indonesia tersebut pelaksanaannya dilakukan oleh Pemerintah, baik Pemerintah Pusat maupun Pemerintah Provinsi dan Kabupaten/Kota. Di Provinsi Sumatera Barat, yang berwenang untuk melaksanakan penggunaan TKAadalah Kementerian Ketenagakerjaan Dinas Tenaga Kerja dan Transmigrasi Provinsi Sumatera Barat dan berkoordinasi dengan Kantor Imigrasi Kelas I TPI Padang.

Pengawasan terhadap orang asing merupakan proses kegiatan di bidang Keimigrasian yang mengumpulkan data dan informasi, menganalisa dan menentukan apakah keberadaan orang asing sejak masuknya di Wilayah Indonesia dan kegiatannya selama berada di Wilayah Indonesia telah sesuai dengan norma yang berlaku baginya.

Secara umum pengawasan terhadap orang asing dilakukan berupa Pengawasan administratif, yaitu: ${ }^{16}$

1) Pengumpulan, pengolahan serta penyajian data dan informasi mengenai : a). Pelayanan keimigrasian bagi orang asing, b). Lalu lintas orang asing yang masuk atau keluar Wilayah Indonesia, c). Orang asing yang telah mendapatkan keputusan pendetensian, d). Orang asing yang dalam proses penentuan status Keimigrasian, e). Orang asing yang mendapatkan izin berada diluar Rumah Detensi Imigrasi setelah

\footnotetext{
${ }^{16}$ Jazim Hamidi dan Charles Christian, 2016. Hukum Keimigrasian Bagi Orang Asing di Indonesia.Jakarta Timur:Sinar:Grafika
} 
terlampauinya jangka waktu pendetensian, f). Orang asing dalam proses peradilan pidana

2) Penyusunan daftar nama orang asing yang dikenai penangkalan atau pencegahan

3) Pengambilan foto dan sidik jari.

Pengawasan Lapangan, Adalah pengawasan yang dilakukan berupa pemantauan, patroli, proses dengan mengumpulkan bahan keterangan pencarian orang, dan alat bukti yang berhubungan dengan Tanda Pengenal Keimigrasian, yang dilakukan sebagai berikut:

1) Pengawasan terhadap keberadaan dan kegiatan orang asing di Wilayah Indonesia, meliputi pengecekan : a). Keberadaan orang asing, b). Kegiatan orang asing, c.) Kelengkapan dokumen perjalan atau izin tinggal yang dimiliki

2) Melakukan kegiatan lain yang dapat dipertanggung jawabkan secara hukum, berupa : a). Melaksanakan kewenangan Keimigrasian sesuai denga ketentuan peraturan perundang-undangan, b). Melakukan koordinasi antar instansi dan/atau lembaga pemerintahan dengan pengawasan Keimigrasian.

Terkait peraturan tentang anggota Tim Pengawasan Orang Asing baik di tingkat Pusat maupun di Daerah tercantum di dalam Pasal 11- 14 Peraturan Menteri Hukum dan Hak Asasi Manusia Nomor 50 Tahun 2016 tentang Tim Pengawasan Orang Asing. Dikarenakan penelitian penulis di Kantor Imigrasi Kelas I Padang, yang mana Kantor Imigrasi berada ditingkat Kabupaten/Kota, maka terkait dengan anggota Tim Pengawasan Orang Asing tercantum di dalam Pasal 13 : Anggota Tim Pengawasan Orang asing ditingkat Kabupaten/Kota paling sedikit memuat dari unsur : a.) Kantor Imigrasi; b). Kepolisian Resor Kota/Kepolisian Resor; c). Kejaksaan Negeri; d). Pemerintah Daerah kabupaten/kota; e). Badan Narkotika Nasional kabupaten/kota; f). Badan Intelijen Negara Daerah; g). Komando Distrik Militer; h). Pangkalan Angkatan Laut/Pos Angkatan Laut; dan i). Pangkalan Udara Angkatan Udara.

Jumlah anggota Tim Pengawasan Orang Asing itu berbeda-beda di setiap tingkat Daerah sesuai dengan dinas terkait dan tidak ada mengenai jumlah pastinya di setiap tingkat Daerah. Terkait dalam melaksanakan tugas dan fungsinya dalam hal pengawasan Kantor Wilayah Kementerian Hukum dan HAM Provinsi Sumatera Barat berkoordinasi dengan Kantor Imigrasi yang berada di Provinsi Sumatera Barat khusunya Kota Padang yaitu Kantor Imigrasi Kelas I Padang yang mana Kantor Imigrasi merupakan salah satu anggota Tim Pora yang berada di tingkat Kabupaten/Kota. 
Dalam hal pengawasan terhadap Dokumen Keimigrasian orang asing, disini penulis akan membahas mengenai Dokumen Keimigrasian orang asing, yaitu:

\begin{tabular}{|l|l|l|l|l|}
\hline No & $\begin{array}{l}\text { Dokumen } \\
\text { Keimigrasian }\end{array}$ & Pelanggaran & $\begin{array}{l}\text { Jumlah Pelanggaran } \\
\text { (tahun 2018) }\end{array}$ & \\
\hline 1. & Visa & Penyalahgunaan Visa & 13 orang & \\
\hline 2. & $\begin{array}{l}\text { Izin Tinggal Orang } \\
\text { Asing }\end{array}$ & $\begin{array}{l}\text { Penyalahgunaan Izin } \\
\text { Tinggal (overstay) }\end{array}$ & 33 orang & \\
\hline \multicolumn{2}{|l|}{ Jumlah } & 46 orang & \\
\hline
\end{tabular}

Sumber: Seksi Pengawasan Kantor Imigrasi Kelas I Padang

Untuk memperkuat pengawasan terhadap orang asing yang datang ke wilayah Sumatera Barat, Kantor Imigrasi Kelas I Padang membentuk Tim Pengawasan Orang Asing di seluruh Kecamatan di seluruh Kabupaten/Kota di Sumatera Barat. Ini akan memaksimalkan fungsi pengawasan orang asing sampai ke daerahdaerah terkecil di Sumatera Barat. Pada saat ini Tim Pora telah dibentuk di 4 Kota dan 7 Kabupaten yaitu Kota Padang, Kota Pariaman, Kota Solok, Kota Sawahlanto, Kabupaten Solok, Sijunjung, Dharmasraya, Pesisir Selatan, Kabupaten Padang Pariaman, Kabupaten Solok Selatan, Kabupaten Kepulauan Mentawai. Tim Pora pada level Kecamatan terdiri dari unsur Camat, Tokoh Adat, Niniak-Mamak, Danramil, Kapolsek, dan Perangkat Kecamatan yang nantinya rutin melakukan rapat evaluasi dan laporannya diberikan kepada Kantor Imigrasi. Mekanisme kerja dari Tim Pengawasan Orang Asing tingkat Kecamatan adalah melakukan pengawasan, kemudian melaporkan jika ada aktivitas dan keberadaan orang asing yang dicurigai kepada Kapolres, Dandim, serta kantor Imigrasi.

Pelaksanaan pengawasan dilaksanakan secara berkala sesuai dengan jadwal pengawasan yang telah ditentukan, yang mana pada Tahun 2018 Seksi Pengawasan Kantor Imigrasi Kelas I Padang telah melakukan pengawasan sebanyak 12-15 kali yang dilakukan secara bersama-sama oleh Tim Koordinasi Pengawasan Orang Asing yang telah dibentuk mulai tingkat Kota, Kabupaten hingga Kecamatan. Tim Pora tersebut bekerja mengawasi orang asing yang beraktivitas di Sumatera Barat terutama daerah yang banyak dikunjungi orang asing seperti Mentawai, Solok Selatan, Kota Padang, dan Sawahlunto.

Dalam pelaksanaan pengawasan tersebut Kantor Imigrasi Kelas I Padang juga menggandeng pihak hotel, atau penginapan untuk melaporkan keberadaan orang asing di daerah mereka menggunakan Aplikasi Pengawasan Orang Asing (APOA), pelaporan itu dilakukan secara daring dalam satu kali 24 jam. Yang mana sejauh ini pelaporan keberadaan orang asing telah berjalan dengan baik terutama penginapan yang berada di Ibukota dan Kabupaten di Sumatera Barat. Tinggal penginapan yang berada di pelosok yang belum memberikan laporan secara maksimal.

Seksi Pengawasan Kantor Imigrasi Kelas I Padang telah mencatat pelanggaran terhadap penyalahgunaan visa oleh orang asing sebanyak 13 orang selama 
Tahun 2018. Setelah dilakukan wawancara dengan orang asing yang melakukan pelanggaran tersebut bahwasannya alasan mereka menyalahgunakan visa tersebut dikarenakan adanya Peraturan Presiden Nomor 21 Tahun 2016 tentang Bebas Visa Kunjungan yang telah membebaskan visa bagi turis asing di 169 negara yang hendak berkunjung ke Indonesia tidak lagi perlu membayar biaya visa jika tujuannya hanya untuk liburan di Indonesia. Dengan bermoduskan berwisata tetapi mereka mencari pekerjaan atau membuka lahan usaha dan menetap di suatu Wilayah tertentu untuk keuntungan pribadi masing-masing. Penyalahgunaan visa itu bisa terjadi karena peluangnya tersedia untuk dilakukan oleh orang asing tersebut. Apalagi faktor-faktor ruang lingkup fasilitas bebas visa yang dinilai sangat luas, termasuk pemberian tenggang waktu pada izin kunjungan wisata yang terlalu lama. Jika memilih bebas visa kunjungan, maka ada batas waktu maksimal untuk berada di Indonesia selama 30 hari dan tidak dapat diperpanjang. Pelaksanaan pengawasan terhadap visa kunjungan belum berjalan efektif dikarenakan faktor internal, diantaranya mengalami kekurangan tenaga kerja yang dikhususkan untuk bertugas melakukan pengawasan serta kurangnya pengawasan dari pihak keimigrasian terhadap warga negara asing yang keluar masuk Wilayah Indonesia dengan menggunakan visa kunjungan.

Pengawasan secara administrasi dan pengawasan lapangan sangat dipengaruhi oleh jumlah personil dalam melaksanakan tugasnya. Pengawasan administratif dan pengawasan lapangan yang dilakukan terhadap orang negara asing di wilayah Indonesia yaitu sebagai dua sistem yang pengawasannya saling berkorelasi satu dengan lainnya. Korelasi tersebut sebagai wujud dari adanya beberapa ketergantungan sistem karena pengawasan lapangan itu tidak selalu dapat dilaksanakan apabila tidak ada temuan hasil pengawasan administratif terhadap penyimpangan mengenai izin tinggal. Selama orang asing tersebut berada di Wilayah Indonesia pengawasan yang dilakukan menyangkut pada aktivitas yang berhubungan dengan batas waktu izin tinggal sementara di Wilayah Indonesia.

Alasan dari orang asing tersebut melakukan pelanggaran izin tinggal tersebut adalah karena mereka ingin lebih lama berada di sini tetapi mereka tidak mau mengeluarkan biaya untuk mengurus perpanjangan dari izin tinggal tersebut serta alasan dari orang asing tersebut karena ketidaktahuan orang asing terhadap peraturan di Indonesia, karena sebagian besar orang asing menyerahkan urusan izin tinggal kepada penjamin/sponsornya. Dalam Pasal 1 angka 25 Undang-Undang Nomor 6 Tahun 2011 tentang Keimigrasian dikatakan bahwa penjamin adalah orang atau koorporasi yang bertanggung jawab atas keberdaan dan kegiatan orang asing selama berada di wilayah Indonesia. Tetapi dalam hal Visa on Arrival yaitu visa yang bisa dibuat saat itu juga pada saat akan masuk ke dalam wilayah suatu negara, baik itu lewat Bandara, Pelabuhan Laut ataupun jalan kaki memasuki perbatasan negara dan pengguna bebas visa kunjungan itu yang menjadi penjamin/sponsornya bisa diri sendiri.

Berdasarkan Pasal 17 Peraturan Menteri Hukum dan HAM Nomor 50 Tahun 2016 tentang Tim Pengawasan Orang Asing dinyatakan bahwa operasi gabungan 
bersifat khusus, yang dilakukan pada waktu atau kegiatan tertentu dan bersifat insedental, yang dilakukan seaktu-waktu dalam hal adanya laporan masyarakat dan anggota Tim Pora. Waktu pelaksanaan operasi gabungan tersebut dilakukan paling sedikit 2 kali dalam setahun berdasarkan hasil rapat Tim Pora. Pengawasan dan penindakan keimigrasian terhadap orang asing merupakan upaya Pemerintah yang sekaligus merupakan ruang lingkup keimigrasian untuk menciptakan keamanan dan ketertiban umum. Secara garis besar fungsi pengawasan dan penindakan orang asing dirumuskan dalam tri fungsi imigrasi, yaitu sebagai aparatur pelayanan masyarakat dan pengamanan negara, penegakan hukum keimigrasian, dan fasilitator ekonomi nasional. Apabila dalam pengawasan ditemukan pelanggaran keimigrasian seperti penyalahgunaan izin tinggal, masa izin tinggal telah habis (overstay), dan tidak memiliki izin tinggal (illegal stay), penyalahgunaan dokumen keimigrasian maka dilakukan tindakan keimigrasian diantaranya tindakan administratif dan pro justitia.

Di bidang ketenagakerjaan juga banyaknya ditemukan TKA ilegal yang bekerja di Indonesia. Berdasarkan data Kementerian Ketenagakerjaan RI, pada akhir tahun 2018 jumlah TKA di Indonesia sebanyak 95.335 orang, angka tersebut meningkat sebesar 10,88\% dari data tahun 2017. ${ }^{17}$ Pada tahun 2017 jumlah TKA di Indonesia sebanyak 85.974 orang, dibandingkan tahun 2018 jumlah TKA bertambah 9.361 orang, peningkatan jumlah TKA di tahun 2018 tersebut terbilang sangat besar di banding tahun-tahun sebelumya, sebagai perbandingan pada tahun 2016 ke 2017 peningkatan jumlah TKA di Indonesia sebesar 5.599,18 tahun 2015 ke 2016 peningakatan jumlah TKA di Indonesia sebanyak 3.226 orang. ${ }^{19}$ Total 95.335 orang TKA pada tahun 2018 tersebut berasal dari berbagai negara, diantaranya sebanyak 32.000 orang dari Cina, 13.897 orang dari Jepang, 9.686 orang dari Korea Selatan dan 6.895 orang dari Malaysia. ${ }^{20}$

Data jumlah TKA pada tahun 2018 tersebut menunjukan jumlah TKA terbanyak berasal dari Cina. Banyaknya jumlah TKA dari Cina tersebut di latar belakangi dari beberapa faktor antara lain:211).Faktor keterbukaan investasi di Indonesia.Sebagaimana kita ketahui saat ini Indonesiasedang giat-giatnya membangun, dan adaprogram Pemerintah dalam rangkapercepatan pembangunan sehingga untukmendatangkan investor dalam satu paketdengan tenaga kerjanya (mulai dari topmanager sampai tenaga buruhnya), 2). Faktor kebijakan bebas visa. Dengandibukanya pintu masuk orang asing tanpavisa (169 negara), maka banyak dari Warga NegaraTiongkok yang datang ke Indonesia, danberdampak pada peningkatan pelanggarankeimigrasian, 3). Pemberlakuan

\footnotetext{
${ }_{17}$ Jumlah TKA Naik Tahun 2018, http://www.tribunnews.com/bisnis/2019/01/14/tahun-2018-tenaga-kerjaasing-naik-1088-persen-kemenaker-nilai-masih-wajar, diakses tanggal 25 April 2019, pukul 20.00 WIB.

${ }^{18}$ Jumlah TKA tahun 2016 sebanyak 80.375 orang dan tahun 2017 sebanyak 85.974 orang.

${ }^{19}$ Jumlah TKA tahun 2015 sebanyak 77.149 orang dan tahun 2016 sebanyak 80.375 orang.

${ }^{20} J u m l a h$ TKA Naik, http://www.tribunnews.com/bisnis/2019/01/14/tahun-2018-tenaga-kerja-asing-naik1088-persen-kemenaker-nilai-masih-wajar, diakses tanggal 25 April 2019, pukul 20.00 WIB.

${ }^{21}$ Ahmad Jazuli, Op. Cit, hlm 93.
} 
Masyarakat Ekonomi ASEAN(MEA). Hal ini menyebabkan terbukanyasekat antar negara (border less) danmeningkatnya kedatangan TKA.

TKA yang ada di Indonesia selain mereka yang masuk secara legal juga ada ditemukan TKA yang bekerja secara ilegal. Kasus-kasus TKA ilegal tersebut semakin banyak ditemukan oleh pihak Dinas Tenaga Kerja dan pihak Imigrasi. Dari hasil introgasi dan investigasi terhadap TKA ilegal yang berhasil ditangkap ditemukan fakta mengenai TKA yang bekerja sebagai buruh kasar, bahkan yang lebih mengejutkan adanya TKA yang bergaji 14-15 juta rupiah perbulan, hal tersebut ditemukan di tambang emas di Kabupaten Nabire, Papua yang ditangkap pada tahun 2018 lalu. ${ }^{22}$

Kasus TKA ilegal ini juga karena dampak dari ketentuan bebas visa untuk 169 negara yang diatur dalam Perpres No. 21 Tahun 2016 tentang Bebas Visa Kunjungan. Para TKA ilegal tersebut banyak diantara mereka yang menyalahgunakan ketentuan bebas visa kunjungan yang seharusnya digunakan untuk berlibur tetapi mereka digunakan untuk bekerja. Seperti temuan dari Ombudsman Republik Indonesia yang menemukan kasus adanya satu perusahaan sekitar 500 orang pekerja asingnya yang menggunakan visa turis. ${ }^{23}$ Dengan adanya bebas visa kunjungan untuk 169 negara tersebut yang bertujuan untuk mendatangkan wisatawan lebih banyak ke Indonesia, dalam kenyataannya tidak menguntungkan bagi negara, karena dari segi jumlah kunjungan wisatawan, tidak ada peningkatakan berarti. Selain itu dari segi ekonomi, dengan adanya ketentuan bebas visa bagi 169 negara terebut juga mengurangi pendapatan negara, karena jika bebas visa kunjungan tidak ada, maka setiap wisatwan dikenakan membayar visa sebesar 25 dolar/orang. ${ }^{24}$ Laode Ida yang menjabat sebagai komisioner Ombudsman RI mengatakan, "negara merugi Rp1 triliun lebih dari Penerimaan Negara Bukan Pajak (PNBP) pada tahun 2016 lalu akibat berlakunya beleid bebas visa kunjungan itu" ${ }^{25}$

Dengan kemudahan syarat masuk bagi TKA ke Indonesia akan mengakibatkan semakin derasnya arus TKA masuk ke Indonesia. Dengan semakin banyaknya jumlah TKA yang masuk ke Indonesia maka juga akan mengakibatkan persaingan untuk mendapatkan pekerjaan bagi rakyat Indonesia semakin ketat dan ujungujungnya akan meningkatnya jumlah pengangguran. Kekhawatiran mengenai TKA ini juga di sampaikan oleh Mirah Sumitra sebagai Presiden Asosiasi Serikat

\footnotetext{
${ }^{22}$ Imigrasi Temukan Tenaga Kerja Asing llegal China Bergaji 40 Juta Rupiah per Bulan, https://www.cnnindonesia.com/ekonomi/20180625150016-92-308852/imigrasi-temukan-tka-ilegalchina-bergaji-rp40-juta-per-bulan, diakses tanggal 28 April 2019, pukul 11.45 WIB.

${ }^{23}$ Ribuan Tenaga Kerja Asing llegal Asal Cina Mengadu Nasib di Indonesia, https://www.cnnindonesia.com/nasional/20180427161601-20-294160/lakon-ribuan-tka-ilegalchina-mengadu-nasib-di-indonesia, diakses tanggal 28 April 2019, pukul 11.45 WIB.

${ }^{24}$ Hasil wawancara dengan Totok Purnawan, Bagian Izin Tingga dan Status Keimigrasian Kantor Imigrasi Kelas I TPI Padang, tanggal 4 April 2019, pukul 11.00 WIB.

25 Ribuan TKA llegal Cina di Indonesia, https://www.cnnindonesia.com/nasional/20180427161601-20294160/lakon-ribuan-tka-ilegal-china-mengadu-nasib-di-indonesia, diakses tanggal 28 April 2019, pukul 11.45 WIB..
} 
Pekerja (ASPEK), Mirah menyatakan pada sebuah konfrensi pers bahwa Pemerintah Indonesia telah menandatangai suatu model investasi asal Cina yang bernama Turkey Project Management. Model investasi Turkey Project Management dari Negara Cina tersebut dalam kontraknya mengehendaki bahwa dalam pengerjaan proyek tersebut menggunakan modal, produk, alat dan tenaga kerja dari Cina. Hal tersebut juga di katakan oleh Dede Yusuf sebagai Ketua Komisi IX DPR RI periode 2014-2019, Dede Yusuf menyatakan Turkey Project Management dengan prinsip menggunakan modal, alat, produk dan tenaga kerja Cina sesungguhnya menciptakan lapangan kerja bagi penduduk Cina. ${ }^{26}$ Aviliani pakar ekonomi dari Indonesia Development of Economics and Finance (Indef) dalam acara Konferensi Internasional Federasi Asosiasi Ekonomi ASEAN (Federation of ASEAN Economics Association/FAEA), menyatakan perusahaan asing termasuk Cina yang berinvestasi di Indonesia menerapkan kebijakan satu paket, yaitu investasi dan tenaga kerja. ${ }^{27}$

Masuknya TKA karena efek liberalisasi yang semakin gencar di dunia dan juga memberi pengaruh ke Indonesia harus dibatasi agar tidak merugikan rakyat Indonesia. Soekarno dan Hatta dalam pandangan mereka mengenai demokrasi sosial ekonomi, Soekarno dan Hatta menolak sistem ekonomi liberal di Indonesia, karena menurut mereka demokrasi liberal seperti yang ada di Eropa Barat hanyalah demokrasi politik yang di bidang sosial ekonomi merugikan rakyat. ${ }^{28}$ Dari pandangan Soekarno dan Hatta tersebut jelas bahwa tujuan awal pendirian Bangsa Indonesia untuk mensejahterakan seluruh Warga Negara Indonesia.

Pengawasan terhadap TKA dilakukan oleh Imigrasi bersama dengan Dinas Tenaga Kerja di daerah. Apabila ada laporan terdapat permasalahan TKA, maka pihak Imigrasi bersama dengan Dinas Tenaga Kerja melakukan pengecekan di daerah yang diduga adanya TKA ilegal. Selanjutnya pihak imigrasi melakukan penyelidikan terhadappelanggaran tersebut, apabila pelanggaran tersebut mempunyai unsur pidana maka, penyidikannya dilaksanakan mengikuti aturan Hukum Acara Pidana. Penyidikan dilakukan oleh Penyidik Pegawai Negeri Sipil (PPNS) Keimigrasian. Hasil dari penyidikan PPNS dapat diteruskan kepada kejaksaan untuk proses hukum selanjutnya atau dapat dikenai sanksi adminsitrasi berupa deportasi apabila TKA bekerja telah lewat waktu yang ditentukan. Selama menunggu waktu untuk pemulangan TKA ke negara asalnya, TKA tersebut di tempatkan di rumah detensi imigrasi karena TKA ilegal tersebut tidak lagi memilki izin tinggal di Indonesia. Kendala dalam pengawasan TKA oleh pihak imigrasi sendiri, ialah dengan banyaknya bandara Internasional yang ada di Indonesia sehingga menjadi banyaknya pintu masuk bagi TKA legal maupun ilegal untuk masuk ke Indonesia. Misalnya TKA yang masuk dari bandara di

\footnotetext{
${ }^{26}$ Turnkey Project Bikin Tiongkok Leluasa Kirim Warga Negaranya Ke Indonesia, https://nusantaranews.co/turnkey-project-bikin-tiongkok-leluasa-kirim-warga-negaranya-ke-indonesia/, diakses pada tanggal 1 Juli 2019, pukul 15.20 WIB.

${ }^{27}$ Ratusan Juta Pengangguran Cina Siap Serbu Indonesia, https://nusantara.news/ratusan-jutapengangguran-cina-siap-serbu-indonesia/, diakses tanggal 1 Juli 2019, pukul 15.50 WIB.

${ }^{28}$ Moh. Mahfud MD, Demokrasi dan Konstitusi Di Indonesia, Rineka Cipta, Jakarta, 2003, hlm 35.
} 
Pekanbaru lalu pergi ke Sumatera Barat lewat jalur darat untuk bekerja yang hal tersebut akan luput dari pantauan pihak imigrasi yang ada di Sumatera Barat. ${ }^{29}$ Dalam jurnal Nevey Varida Ariani, mengenai permasalah pengawasan TKA, dinyatakan:

Pengawasan terhadap tenaga kerja asingmasih lemah karena jumlah pengawas tidaksebanding dengan jumlah perusahaan termasukjumlah perusahaan yang muncul karena investasi,selain jumlah Kantor Imigrasi yang terbatas untuk mengawasi gerak-gerik tenaga kerja asing ilegal. Dari $514 \mathrm{Kab} / \mathrm{kota}$, hanya ada 185 kantor cabang Imigrasi. ${ }^{30}$

Pengawasan TKA oleh Dinas Tenaga Kerja dan Transmigrasi Provinsi Sumatera Barat dilakukan untuk memastikan kebenaran data mengenai TKA dan pemberi TKA melaksanakan peraturan perundang-undangan, Dinas Tenaga Kerja dan Transmigrasi Provinsi Sumatera Barat melakukan pengawasan TKA yang dilakukan bersama dengan pihak Imigrasi. Terhadap bidang kerja yang bisa dilakukan oleh pekerja Indonesia maka TKA tidak boleh lama berada pada bidang kerja tersebut, karena pada dasarnya penggunaan TKA untuk memberikan pengetahuan pada pekerja Indonesia dan jika pekerja Indonesia sudah bisa melakukan suatu bidang pekerjaan yang diisi oleh TKA, maka bidang tersebut wajib diduduki oleh pekerja Indonesia yang hal tersebut merupakan bentuk perlindungan bagi hak akan pekerjaan bagi pekerja Indonesia. Di Sumatera Barat, bentuk perlindungan terhadap kesempatan kerja bagi pekerja Indonesia adalah dengan dibatasinya TKA yang bekerja di Sumatera Barat.

\section{B. Kendala dalam Pengawasan Tenaga Kerja Asing di Sumatera Barat}

Orang asing yang datang ke Sumatera Barat melalui Bandara Internasional Minangkabau pada Bulan Desember 2018 adalah berjumlah 4.801 orang, yang mengalami penurunan sebesar 6,19\% dibanding Bulan November sejumlah 5.118 orang. Tingginya tingkat kedatangan orang asing di Sumbar tidak luput dari suatu pelanggaran dan juga membuat pengawasan tidak berjalan efektif dikarenkan jumlah personil di bidang pengawasan yang sangat sedikit yang tidak sebanding dengan tingginya kedatangan orang asing.

Dalam rangka penegakan hukum sekaligus menjaga kewibawaan hukum, sebagai tindak lanjut dari pengawasan, khususnya pengawasan orang asing yang berada di Indonesia dan penanganan keimigrasian pada umumnya, penindakan merupakan satu hal yang sangat penting dan harus dilaksanakan. Sisi lain dari pelaksanakaan penindakan atas pelanggaran adalah demi tegaknya hukum dan untuk menjamin kepastian hukum di wilayah Repuublik Indonesia. Dalam hal melaksanakan pengawasan tentu saja petugas Kantor Imigrasi khususnya bagian Seksi Pengawasan menemukan beberapa kendala sehingga membuat pelaksanaan pengawasan tidak berjalan efektif, di antaranya kendala-kendala

\footnotetext{
${ }^{29}$ Hasil wawancara dengan Yusa, Bagian Subseksi Pengawasan Orang Asing Kantor Imigrasi Kelas I TPI Padang, tanggal 4 April 2019, pukul 12.00 WIB.

${ }^{30}$ Nevey Varida Ariani, "Penegakan Hukum Terhadap Tenaga Kerja Asing Ilegal di Indonesia", Jurnal De Jure, 2018, hlm 124.
} 
tersebut disebabkan oleh: 1). Adanya keterbatasan jumlah petugas imigrasi yang di tempatkan di bagian pengawasan orang asing yang tidak sebanding dengan luas wilayah yang menjadi target pengawasan wilayah kerja Kantor Imigrasi Kelas I Padang. Dengan jumlah 3 (tiga) orang sub Seksi Pengawasan pada Kantor Imigrasi Kelas I Padang tidak bisa melakukan pengawasan secara efektif, 2). Luasnya cakupan wilayah kerja Kantor Imigrasi Kelas I Padang, yaitu 4 Kota 7 Kabupaten Kota : Padang, Solok, Pariaman, Sawahlunto Kabupaten : Pesisir Selatan, Padang Pariaman, Solok, Dharmasraya, Sijunjung, Solok Selatan, Mentawai, 3). Menyangkut kebiasaan masyarakat yang lebih bersifat apatis, tidak mau tahu dengan keberadaan orang asing. Menjadi kesulitan pula bagi Kantor Imigrasi Kelas I Padang dalam melakukan pengumpulan data di lapangan.

Untuk Dinas Tenaga Kerja Provinsi Sumatera Barat, dalam pengawasan penggunaan TKA juga terdapat kendala, yaitu: Adanya kemudahan dan penyederhanaan perizinan TKA dalam Pepres No. 20 Tahun 2018, antara lain: a). erpres No. 20 Tahun 2018 tidak lagi mensyaratkan bagi pemberi kerja untuk memiliki Izin mempekerjakan TKA (IMTA) seperti ketentuan dalam Perpres sebelumya, karena fungsi RPTKA sebelum Perpres 20 Tahun 2018 merupakan syarat untuk mendapatkan izin mempekerjakan TKA, sekarang menurut ketentuan Pasal 9 Perpres No. 20 Tahun 2018 RPTKA merupakan izin mempekerjakan TKA, b). Pasal 6 Perpres No. 20 Tahun 2018 menyatakan TKA dapat bekerja pada dua pemberi kerja sekaligus dalam waktu bersamaan, c). Jangka waktu pengesahan dan perubahan RPTKA paling lama 2 (dua) hari sejak permohonan diterima secara lengkap seperti ketentuan Pasal 8 dan 12 Perpres No. 20 Tahun 2018, d). Pasal 13 Perpres No. 20 Tahun 2018 menyatakan, untuk pekerjaan yang bersifat darurat dan mendesak pemberi kerja dapat mempekerjakan TKA terlebih dahulu sebelum adanya pengesahan RPTKA dari Menteri atau Pejabat yang ditunjuk, e). Pasal 19 Perpres No. 20 Tahun 2018 menyatakan Visa Tinggal Terbatas bagi TKA diberikan paling lama 2 (dua) hari sejak permohonan diterima secara lengkap oleh Pejabat Imigrasi pada Perwakilan Republik Indonesia di luar negeri, f). Pasal 20 Perpres No. 20 Tahun 2018 menyatakan, Visa Tinggal Terbatas dan Izin Tinggal terbatas dapat diajukan permohonannya sekaligus

Kendala yang dialami oleh Dinas Tenaga Kerja dan Transmigrasi Provinsi Sumatera Barat terhadap pengawasan TKA adalah mengenai perizinan TKA yang hanya dilakukan oleh Pemerintah Pusat yaitu Kementerian Ketenagakerjaan, sehingga mengakibatkan tidak adanya data pasti yang dimiliki oleh Dinas Tenaga Kerja dan Transmigrasi Provinsi Sumatera Barat selain yang dilaporkan langsung oleh pemberi kerja TKA. Padahal seharusnya dalam Pasal 31 Perpres No. 20 Tahun 2018 mengatur bahwa Kementerian Ketenagakerjaan harus menyampaikan data TKA kepada unit kerja Pemerintahan Provinsi/Kabupaten/Kota yang membidangi ketenagakerjaan sesuai dengan lokasi kerja TKA. Dengan keadaan demikian, menandakan belum berjalannya pelaporan data TKA dari Kementerian Ketenagakerjaandan integrasi online data TKA antara Kementerian Ketenagakerjaan dan Dinas Tenaga Kerja Provinsi. 
UIRLawReview. 5(1): 30-48

\section{Penutup}

Dari hasil Penelitian yang dilakukan, dapat ditarik kesimpulan:

Pengawasan atas penggunaan TKA menurut Pasal 33 ayat (1) Perpres No. 20 Tahun 2018 dilaksanakan oleh pengawas ketenagakerjaan pada Dinas Provinsi yang membidangi urusan di bidang ketenagakerjaan dan pegawai Imigrasi yang bertugas pada bidang pengawasan dan penindakan Keimigrasian. Dari penelitian yang dilakukan di Kantor Imigrasi Kelas I TPI Padang dan Dinas Tenaga Kerja dan Transmigrasi Provinsi Sumatera Barat. Pengawasan terhadap TKA dilakukan oleh Imigrasi bersama dengan Dinas Tenaga Kerja di daerah. Apabila ada laporan terdapat permasalahan TKA, maka pihak Imigrasi bersama dengan Dinas Tenaga Kerja melakukan pengecekan di daerah yang diduga adanya TKA ilegal.

Kendala dalam Pengawasan terhadap TKA dilakukan oleh Imigrasi bersama dengan Dinas Tenaga Kerja di daerah. Apabila ada laporan terdapat permasalahan TKA, maka pihak Imigrasi bersama dengan Dinas Tenaga Kerja secara umum adalah keterbatasan jumlah pengawas serta luasnya cakupan wilayah yang diawasi. Sikap masyarakat yang apatis dan tidak mau melaporkan adanya TKA illegal juga menjadi kendala dalam pengawasan penggunaan Tenaga Kerja Asing. 
UIRLawReview. 5(1): 30-48

\section{Daftar Pustaka}

Abdul Khakim, Hukum Ketenagakerjaan Indonesia Berdasarkan Undang-undang Nomor 13 Tahun 2003, PT. Citra Aditya Bakti, Bandung, 2003.

Adrian Sutedi, Hukum Perburuhan, Sinar Grafika Offset, Jakarta, 2009.

Edi Cahyono, "Tenaga Kerja Asing (TKA) Dalam Perspektif Masyarakat Ekonomi ASEAN (MEA): Peluang atau Ancaman Bagi SDM Indonesia", Jurnal Bisnis, Manajemen dan Akuntansi, 2016.

Fankiano B Randang, Kesiapan Tenaga Kerja Indonesia dalam menghadapi Persaingan Tenaga Kerja Asing, Servanda, Jurnal IImiah Hukum vpl, 5 No.1, Januari 2011, ISSN 1907-162030, 2011.

Jazim Hamidi dan Charles Christian, Hukum Keimigrasian Bagi Orang Asing di Indonesia.Jakarta Timur:SinarGrafika, 2016.

Khairani, Pemgantar Hukum Perburuhan dan Ketenagakerjaan,RajaGrafindo Persada, Depok, 2018.

Lalu Husni, Pengantar Hukum Ketenagakerjaan Indonesia, PT. Raja Grafindo Persada, Jakarta, 2000.

Monica Claudya Suhendra, Pengawasan Terhadap Dokumen Keimigrasian Orang Asing di Kantor Imigrasi Kelas I Padang, Skripsi, Fakultas Hukum Universitas Andalas, 2019.

Muhammad Faisal, Penggunaan Tenaga Kerja Asing Dikaitkan dengan Perlindungan Terhadap Hak Warga Negara Indonesia atas Pekerjaan, Tesis, Fakultas Hukum Universitas Andalas, 2019.

Ratna Tria Maris, Perlindungan Keselamatan dan Kesehatan Kerja Bagi Tim Pekerjaan Dalam Keadaan Bertegangan Menengah Di PT. Perusahaan Listrik Negara (Persero) Area Padang, Skripsi, Fakultas Hukum Universitas Andalas, 2013.

Ridwan HR, Hukum Administrasi Negara, Rajawali Pers, Jakarta, 2013

Zaeni Asyhadie, Hukum Kerja,Hukum Ketenagakerjaan Bidang Hubungan Kerja, PT. RajaGrafindo Persada, Jakarta, 2007.

Undang-Undang Dasar Negara Republik Indonesia Tahun 1945

Undang-undang Nomor 1 Tahun 1970 Tentang Keselamatan Kerja

Undang-undang Nomor 13 Tahun 2003 Tentang Ketenagakerjaan

Undang-undang Nomor 3 Tahun 1992 Tentang Jaminan Sosial Tenaga Kerja

Peraturan Pemerintah Nomor 14 Tahun 1993 Tentang Penyelenggaraan Program Jaminan Sosial Tenaga Kerja yang diubah dengan Peraturan Pemerintah Nomor 79 Tahun 1998 Tentang Perubahan atas Peraturan Pemerintah Nomor 14 Tahun 1993 Tentang Penyelenggaraan Program Jaminan Sosial Tenaga Kerja.

Keppres Nomor 22 Tahun 1993 Tentang Penyakit yang Timbul Karena Hubungan Kerja Perpres Nomor 21 Tahun 2010 Tentang Pengawasan Ketenagakerjaan 
UIRLawReview. 5(1): 30-48

Peraturan Menteri Tenaga Kerja Nomor 5 Tahun 1996 Tentang Sistem Manajemen Keselamatan dan Kesehatan Kerja

Peraturan Menteri Tenaga Kerja dan Transmigrasi Nomor PER.08/MEN/VII/2010 tentang Alat Pelindung Diri

Perda Kabupaten Sijunjung No 3 Tahun 2014 Tentang Pengelolaan Pertambangan Mineral dan Batubara

http://www.hpli.org/tambang.php

http://agungovestsum.blogspot.com/2012/09/potensi-kekayaan-sumatera-barat.html

http://www.tribunnews.com/regional/2014/01/24/tambang-batu-bara-di-sawahluntomeledak-sebabkan-satu-pekerja-tewas

http://www.metrotvnews.com/metronews/read/2014/01/24/6/210530/Tambang-diSawahlunto-Meledak-1-Meninggal-4-Orang-Terjebak. Jum'at 24 Januari 2014

http://www.syafrilhernendi.com/312/pekerja-tambang-bawah-tanah-profesipenantang-bahaya-1/ 